\title{
POPULISM IN ELECTION TIMES: A COMPARATIVE ANALYSIS OF ELEVEN COUNTRIES IN WESTERN EUROPE
}

Laurent Bernhard ${ }^{\mathrm{a}}$ and Hanspeter Kriesi ${ }^{\mathrm{b}, \mathrm{c}}$

${ }^{\text {a}}$ Swiss Centre of Expertise in the Social Sciences (FORS), University of Lausanne, Lausanne, Switzerland; 'bepartment of Political and Social Sciences, European University Institute, San Domenico di Fiesole (Florence), Italy; 'Laboratory for Comparative Social Research, National Research University Higher School of Economics, Moscow, Russian Federation

CONTACT: Laurent Bernhard laurentbernhard@fors.unil.ch

\begin{abstract}
The article comparatively examines the levels of populism exhibited by parties in Western Europe. It relies on a quantitative content analysis of press releases collected in the context of eleven national elections between 2012 to 2015. In line with the first hypothesis, the results show that parties from both the radical right and the radical left make use of populist appeals more frequently than mainstream parties. With regard to populism on cultural issues, the article establishes that the radical right outclasses the remaining parties, thereby supporting the second hypothesis. On economic issues, both types of radical parties are shown to be particularly populist. This pattern counters the third hypothesis, which suggests that economic populism is most prevalent among the radical left. Finally, there is no evidence for the fourth hypothesis, given that parties from the South do not resort to more populism on economic issues than those from the North.
\end{abstract}

\section{KEYWORDS:}

\section{Introduction}

In the first decades immediately following World War II, populism was a rather marginal phenomenon in Western Europe (Gellner and Ionescu 1969). In contrast to many other regions, conventional wisdom had long maintained that populism would have a hard time establishing itself in this part of the world (Priester 2012: 11). However, in the course of the last 30 years, this has fundamentally changed. Numerous parties commonly labelled as 
populist have managed to establish themselves as powerful players in the political landscapes of their respective countries.

Indeed, populist success stories are apparent across the entire region. In electoral terms, SYRIZA from Greece (35.5 per cent) is now the strongest party of this type, followed by the Five Star Movement from Italy (32.7 per cent), the Swiss People's Party (29.4 per cent) and the Danish People's Party (21.2 per cent). More recently, several populist parties have even been part of national governments. The most striking case concerns the Greek populist coalitions between SYRIZA and ANEL, as well as the Five Star Movement and Lega in Italy. Other populist forces in office include the Finns, the Progress Party in Norway, the Swiss People's Party and the Austrian FPÖ.

Following the influential definition provided by Mudde (2004: 543), the article conceives populism as a 'thin ideology that believes society to ultimately be separated into two homogenous and antagonistic groups - 'the pure people' versus the 'corrupt elite'- and which argues that politics should be an expression of the volonté générale (general will) of the people'. This minimal conceptualisation allows for the analytical advantage of studying the populist phenomenon in various forms and comparatively across countries (Rovira Kaltwasser 2012). As far as the operationalisation of the populist ideology is concerned, the article relies on the communication of political actors. Our measure of populism essentially includes three types of appeals - people-centrism, anti-elitism and demands for popular sovereignty, which correspond to the three ideational elements in Mudde's definition. ${ }^{1}$

The empirical part of this article relies on a quantitative content analysis of press releases collected in the context of eleven national election campaigns that occurred between 2012 and 2015. We consider all parties that obtained at least four per cent of the vote in these elections.

\footnotetext{
${ }^{1}$ This focus on key elements implies that the authors refrain from considering disputed characteristics of populism, such as charismatic leadership, mobilisation logics (bottom-up vs. top-down) and stylistic features (e.g. simplification, emotionalisation and personalisation).
} 
The main research interest focuses on the role played by party families. The article argues that parties from both the radical right and the radical left outclass mainstream parties in terms of populism (first hypothesis). In addition, the article takes a closer look at issue dimensions. The second and third hypotheses expect radical right parties to be more populist on cultural issues and the radical left to be more populist on economic issues. In addition, the article examines the presumed divide between the South and the North of Europe. As a result of the severity of the Great Recession, the fourth hypothesis posits that parties from the South of Europe are generally more likely to rely on economic populism than their peers in the Northern part.

In line with the first hypothesis, there is evidence that parties on the ideological extremes express populist ideology in their campaign communication. More specifically, we find that both the radical right and the radical left play the 'populist card' more frequently than mainstream parties. With respect to issue domains, the empirical analysis demonstrates that the radical right excels in terms of cultural populism, thereby supporting the second hypothesis. The empirical analysis further reveals that both radical groups tend to engage in economic and cultural populism, thus contradicting the third hypotheses. In addition, the analysis shows that parties from the South are not more prone to rely on populism on economic issues than those from the North, thus leading to a rejection of the fourth hypothesis. However, the results reveal that Greek parties outclass their peers in the remaining countries when it comes to economic populism.

This article continues as follows. The next section focuses on the populisms by the radical right and the radical, before addressing the North-South divide in the context of the European debt crisis. The article proceeds by presenting the key features of the case selection, the data collection and the construction of the indicators. In the subsequent section, the authors present 
the empirical results. The article concludes by critically reviewing the main results of the contribution and drawing some implications.

\section{The Populism(s) of Radical Parties}

The following section relies on a minimal and ideational conceptionalisation of populism. Defined as a thin ideology (Mudde 2004), populism has the potential to come in various guises. Mény and Surel (2002: 6) compare populism to an empty shell that can be filled and made meaningful by whatever is poured into it. Indeed, extensive studies reveal that populist mobilisations have not only occurred across different places and times but that they have also taken very different forms (Canovan 1981; Hermet 2001). Amongst others, such mobilisations included agrarian revolutionary romanticism in Tsarist Russia, US agrarian radicalism in the $19^{\text {th }}$ century and urban mass movements in $20^{\text {th }}$ century Latin America.

While the populist phenomenon is far-reaching enough to include both right- and left-wing variants, most scholars of contemporary Western Europe associate it with the radical right (e.g. Betz 1993; Mudde 2007; Mudde 2010). The abundant literature suggests that most of these parties rely on populism. It is well established that the radical right has often met with electoral success in many Western European countries by repeatedly tapping into people's resentments against the establishment regarding the cultural dimension of the twodimensional policy space (Hooghe et a. 2002; Kriesi et al. 2008). ${ }^{2}$ In addition to their populism, these actors have been able to capitalise on widespread popular xenophobia. The ideology of the radical right does not necessarily involve ethnic racism but rather refers to

\footnotetext{
${ }^{2}$ When it comes to major political conflicts in contemporary Western Europe, political scientists typically draw a distinction between economic and cultural policy dimensions. While the former refers to the opposition between state interventions and market solutions, the latter contrasts libertarian and cosmopolitan values with authoritarian and nationalist values.
} 
‘differentialist nativism’ or ‘cultural differentialism' (Betz and Johnson 2004), i.e. a sharp rejection of multicultural society more generally.

At the same time, the state of the art suggests that it is not possible to simply equate populism with the radical right in Western Europe (van Kessel 2015: 172). On the contrary, left populism no longer seems to be a marginal phenomenon in Western Europe. Despite the fact that there is still little reference to this phenomenon, in recent years, parties from the radical left have increasingly been identified with populist ideologies. Most significantly, March (2007: 67) argues that the collapse of communism has opened the space for a new type of left populism. Many communist parties have abandoned their doctrinaire and conservative forms of organised socialism, while Social Democrats have moved to the centre, thereby increasing the perception that the mainstream left is an integral part of the establishment. More recently, the Great Recession may have fostered an affinity between socialism and populism (March 2011: 121), especially among parties from the radical left whose ideas gained currency after the Great Recession (March and Keith 2016).

Comparative studies have focused on the ideological dimension of populism so far. Several comparative analyses of party manifestoes (Pauwels 2014; Rooduijn and Pauwels 2011; Rooduijn et al. 2014; Roodujn and Akkerman 2015) suggest that parties such as the Dutch SP, the French Communist Party and The Left in Germany run on populist platforms. In the case of the United Kingdom, March (2017) shows that on both sides of the left-right divide, the degree of populism by radical parties is higher than the degree in mainstream parties. Roodujn and Akkerman (2015) arrive at the same conclusion based on the analysis of the election manifestoes of 32 parties in five countries (France, Germany, Italy, the Netherlands and the United Kingdom) from 1989 to 2008. Similarly, based on the holistic grading of party manifestoes and candidate speeches in Western Europe and the Americas, Castanho Silva 
(2017) finds that populism in Europe is associated with extremism in general, and not necessarily with either left or right politics.

Populism seems to be characteristic of parties on the extremes of the ideological spectrum the radical right and the radical left. Hence, the first hypothesis reads as follows:

H1: Parties from the radical right and the radical left adopt a higher degree of populism than mainstream parties.

While all kinds of populism are characterised by people-centrism, anti-elitism and demands for popular sovereignty, there is a great deal of variation in its more substantive features. Generally speaking, the academic literature draws a clear distinction between right and left populisms. According to Mudde and Rovira Kaltwasser (2013), the former tends to be exclusionary in nature, while the latter follows an inclusionary logic. The authors distinguish between three dimensions: material (i.e. the distribution of resources among social groups), political (i.e. the appeal to forms of political mobilisation) and symbolic (i.e. the notion of 'the people').

In line with Mény and Surel (2002), the article argues that the populist variation across the ideological divide is most visible in the symbolic dimension. Populists from the right define people using ethnic terms. As Rydgren (2013:2) observes, such parties share an emphasis on ethno-nationalism that is rooted in myths about the distant past. They thus direct their program to strengthen the nation by making it more ethnically homogeneous. It is now well established that the radical right has been the driving force of a cultural conflict dimension that opposes universalistic and traditionalist-communitarian values in Western Europe (Bornschier 2010; Kriesi et al. 2008). This party family primarily opposes cosmopolitan conceptions of society, since it undermines national sovereignty and local identities. 
In contrast, populists from the left conceive of the people in terms of socio-economic categories. Given the prevalence of egalitarian ideals, left populism primarily expresses itself on economic issues (March 2007) by emphasising a moral opposition between the virtuous working classes, on the one hand, and the oppressive representatives of capital on the other hand. The latter are held responsible for economic and political inequalities (March and Mudde 2005). Based on these considerations, the populism expressed by the radical left is expected to more likely focus on economic issues, while the radical right is more likely to concentrate on cultural issues. These considerations lead to the second and third hypotheses.

H2: Parties from the radical right displays a higher level of populism than the remaining parties when cultural issues are at stake.

H3: Parties from the radical left adopt a higher level of populism than the remaining parties when it comes to economic issues.

\section{The North-South Divide}

According to Canovan (1999), the rise of populism is an indication of political malaise in modern societies. Following this line of reasoning, populism arises from the gap between the promise and the actual performance of democracies. In other words, populists challenge how democracy works in the name of its imagined ideal. The fundamental tension between the redemptive and the pragmatic face of politics provides a fertile ground for populist demands. In particular, the populist potential increases when this discrepancy widens. As Canovan (1999: 12) maintains, 'when too great a gap opens up between haloed democracy and the grubby business of politics, populists tend to move on to the vacant territory, promising in place of the dirty world of party manoeuvring the shining ideal of democracy renewed'. In line with this statement, several scholars of populism identify deep crises as major catalysts for the emergence and reinvigoration of populism. This is probably most visible in the work 
of Ernesto Laclau, where populism is intrinsically linked to a crisis of representation (Howarth 2015). Taggart (2000: 2), for his part, conceives of populism as a reaction to a sense of extreme crisis, stating that politics as usual cannot deal with such unusual conditions. In a similar vein, Panizza (2005: 11) regards crises as crucial conditions for populism, since such events imply a breakdown of social order and a loss of confidence in the political system's ability to restore it.

Following this logic, economic crises provide a major opportunity for successful populist mobilisations. In a recent contribution on the Great Recession, Kriesi and Pappas (2015: 23) posit that populism has benefited from the financial and economic crisis, since popular dissatisfaction with elites increased in this particular context. In electoral terms, however, Kriesi and Pappas (2015) observe considerable regional variations. Most notably, the authors point to a strong increase in populists' vote share in Southern Europe. Indeed, fuelled by the serious economic crisis, some populist parties such as SYRIZA (Greece) or the Five Star Movement (Italy) have recently experienced tremendous electoral successes, sometimes leading to the destabilisation of national party systems.

This suggests that the potential for populism is generally more pronounced in countries that have suffered most from the economic crisis and its disastrous consequences. Although the Great Recession hit all European countries in late 2008, it did so to a very different extent (Lane 2012). While most countries in the North recovered rapidly, economic landing proved to be generally hardest in the South. By 2016, some economies in Southern Europe were still far from pre-crisis levels of GDP. Particularly worrisome for these economies was the fact that the share of unemployed workforce reached new record highs, especially among younger people.

According to this line of reasoning, the Great Recession widened the gap between citizens' expectations and what established parties can actually deliver. Hence, parties that address the 
antagonistic relationship between 'guilty' elites and 'innocent' people are likely to make headway. Voters may be receptive to the discourse of populist parties who seek to challenge the mainstream political consensus that revolves around a discourse according to which 'there is no alternative' (Hobolt and Tilley 2016). In a cross-sectional setting, parties from the South are thus hypothesised to more frequently pursue a populist discourse in the context of the European debt crisis than their peers from the Northern part of Western Europe. Hence, the fourth hypothesis:

H4: Parties from the South adopt a higher level of populism than the parties from the North when it comes to economic issues.

\section{Data and Measures}

This study focuses on national election campaigns. From a researcher's perspective, such periods provide the advantage of a heightened intensity in political communication. The extent of populist messages can also be expected to increase in the context of election campaigns compared to 'ordinary politics' (Bernhard et al. 2015). In what follows, the article will examine eleven national elections - one per selected country - that took place in Western Europe between 2012 and 2015. The limited time frame presents the advantage of examining similar contextual conditions (such as presumably salient public debates on the Great Recession or the refugee crisis). This study analyses ten parliamentary elections (Austria 2013, Germany 2013, Greece January 2015, Italy 2013, the Netherlands 2012, Portugal 2015, Spain 2015, Sweden 2014, Switzerland 2015 and the United Kingdom 2015), as well as one presidential election (France 2012).

The rationale driving country selection stems from the objective to include at least one representative example of the main regions in Western European. The authors therefore select one Anglo-Saxon (UK) case, one Scandinavian (Sweden) case and five cases from continental 
Europe (Austria, France, Germany, the Netherlands and Switzerland) for the sample. Given the key interest in the crisis-ridden Southern region, the authors include its four biggest countries (Italy, Spain, Greece and Portugal). With respect to parties, the selection is based on one single criterion. The authors include all parties that obtained vote shares higher than four per cent in the national elections under scrutiny. These 63 parties are assigned to three different ideological groups: 1) radical left, 2) mainstream and 3) radical right. The second category is the most encompassing one by far, as it includes the following party families: the Greens, the Socialists and Social Democrats, the Liberals, as well as Christian Democrats and Conservatives.

Among the selected parties, the Italian Five Star Movement (M5S) proved to be the most challenging case. This is in line with several scholarly contributions that highlight the rather unconventional profile of the party co-founded by Beppe Grillo (Bordignon and Ceccarini 2013; Conti and Memoli 2015). According to Biorcio (2015), the orientation of the M5S, and its operation as a direct-democratic organisation, pointed to its affiliation the left in its early years. This has only changed recently. Given that the article analyses the 2013 Italian general elections, the Five Star Movement is eventually considered to be a functional equivalent of a radical left party. However, the authors test for alternative classifications in the empirical analysis. ${ }^{3}$ Table 1 provides an overview of the parties included in the analysis, classified by country and ideological group.

\footnotetext{
${ }^{3}$ The main findings of this study are not affected by the classification of the Five Star Movement.
} 
Table 1: Selected parties according to countries and ideological groups

\begin{tabular}{|l|lll|}
\hline Election & Radical left & Mainstream parties & Radical right \\
\hline Austria 2013 & - & ÖVP, SPÖ, Greens, TS, NEOS & FPÖ \\
France 2012 & FDG & PS, UMP, MoDem & FN \\
Germany 2013 & Linke & CDU, SPD, Greens, FDP & AfD \\
Greece 2015 \#1 & SYRIZA, KKE & ND, To Potami, PASOK & XA, ANEL \\
Italy 2013 & M5S* & PD, PdL, SC & LN \\
The Netherlands 2012 & SP & VVD, PvdA, CDA, D66 & PVV \\
Portugal 2015 & BE, PCP & PPD/PSD, PS & - \\
Spain 2015 & Podemos & PP, PSOE, C's & - \\
Sweden 2014 & V & S, M, MP, C, FP, KD & SD \\
Switzerland 2015 & - & FDP, SP, CVP, GPS, GLP BDP & SVP \\
United Kingdom 2015 & - & Tories, Labour, Lib Dems, SNP & UKIP \\
\hline
\end{tabular}

* As is explained in the data and measures section, the Five Star Movement (M5S) is classified as a radical left party.

Notes: Within ideological groups, the selected parties are ordered according to declining vote shares. The People of Freedom (PdL) from Italy had to be excluded from the empirical analysis due to a lack of press releases. The full names of the remaining parties are listed in Table A.1 of the Appendix.

This paper relies on press releases issued by political parties during national election campaigns in the course of the last eight weeks prior to Election Day. The authors opt to use this type of communication due to motives of comparability. Parties across Western Europe widely use press releases and they exhibit quite similar formats and lengths. The press releases originate from the party websites. It is worthwhile to mention that the authors faced difficulties in finding appropriate campaigning material for three organizations - the Party for Freedom, from the Netherlands, the Five Star Movement and the People of Freedom (both from Italy). In face of a lack of classic press releases, the authors proceeded as follows. In the case of the Party for Freedom, the short news articles that were available on the party's website were selected. Regarding the Five Star Movement, the posts published on Beppe Grillo's personal blog were content-analysed. The only party for which no appropriate documents could be found is the People of Freedom. Silvio Berlusconi's party obviously did 
not make sufficient use of press releases and the like in the context of the 2013 Italian general elections. ${ }^{4}$ Hence, the present empirical analysis covers 62 different political parties.

The following section outlines our indicators of populism. As part of its conception as a thin ideology, political actors can express populism in specific discursive patterns. Several authors usefully propose indices to operationalise populist beliefs based on an analysis of the discursive pattern of political texts, such as party manifestoes, speeches or press releases (see Aslanidis 2015; Bruhn 2012; Jagers and Walgrave 2007; March 2017; Pauwels 2011;

Rooduijn et al. 212; Rooduijn and Pauwels 2011). In this empirical analysis, the authors of this article share a similar approach by using a quantitative content analysis of the parties' press releases. Based on Wirth et al. (2016), the coding of populism relies on its three core ideational concepts -people-centrism, anti-elitism and popular sovereignty. The unit of analysis refers to statements made by individuals (e.g. politicians) and organizations (typically political parties) about specific political issues. Following the guidelines of the codebook, a new statement was coded as soon as a hitherto unaddressed issue was available in a given press release. Depending on the thematic structuring of the selected texts, issue-specific statements can thus include a single sentence, a paragraph or even an entire document. In such issue-specific statements, political actors can potentially address all three populist sub-dimensions. According to the codebook, they use people-centrist rhetoric if they a) stress the virtues of the people, b) stress the achievements of the people, c) demonstrate closeness to the people and d) assert a monolithic people. Anti-elitist appeals include strategies that they a) denounce elites, b) blame elites or c) exclude elites from the people. Finally, two indicators are used to capture popular sovereignty: a) demanding sovereignty of the people and b)

\footnotetext{
4 This might be due to the fact that the PDL, to a large extent, enjoyed direct media access thanks to the companies owned by Mediaset - very close to Silvio Berlusconi.
} 
denying sovereignty to the elites. ${ }^{5}$ For each sub-dimension, the authors created an index ranging from zero to one. Subsequently, these three measures were summed up, given that a Mokken analysis revealed that those components form a hierarchical scale. The populism indicator thus theoretically ranges from zero to three. In this context, it seems important to highlight populism has not to be regarded as an all-or-nothing phenomenon but as a matter of degree (Rooduijn and Pauwels 2011). According to this gradual logic, political actors can adopt more or less discourses on people-centrism, anti-elitism and appeals to popular sovereignty.

Altogether, 11,356 statements about issues or actors have been coded from the selected press releases (see Table A.1 in the Appendix). We calculated the average populist communication level per statement for each party. The mean score across the 62 parties included is 0.050 . At first glance, this low level suggests that political actors do not often make use of populist rhetoric in press releases. While it is true that there is no indication of populism in a majority of coded statements, it needs to be mentioned that the coding scheme precludes high scores of populist communication. Indeed, it is hard to conceive of political actors who articulate nine different specific criteria of populist appeals at the level of single statements throughout a substantial amount of campaign documents. Importantly, even if the level of populist communication measured is low overall, it varies substantially across parties (s.d. $=0.047)$. When looking at the three main components of populism, anti-elitist appeals prove to be the most often used $(\mathrm{M}=0.030)$, followed by people-centrist rhetoric $(\mathrm{M}=0.014)$. It appears that political actors largely refrained from demanding popular sovereignty for the people $(\mathrm{M}=0.06)$.

\footnotetext{
${ }^{5}$ The coding of the selected press releases was undertaken by 34 native speakers or highly qualified academics. Inter-coder reliability tests of this coding scheme produced satisfactory results (Cohen's Kappa $>0.5$ ).
} 
With respect to the level of populism according to issue domains, the authors use the twelve broad categories employed by Kriesi et al. (2008). ${ }^{6}$ The authors assigned actor statements about the welfare state, economic liberalism, public finances, education and infrastructure to the economic domain, while they coded statements that address policies related to cultural liberalism, immigration, the army and security matters as cultural issues. Based on a reviewer's comment, a differentiated strategy was implemented regarding the European integration process. Using the level of sub-issues as classification criterion, the authors decided to consider general statements, as well as those related to national sovereignty, enlargement, international cooperation, democratic institutions, security and migration, as belonging to the cultural domain. In contrast, the authors include statements about free trade, market regulations, social questions, the Euro and the economic crisis as part of the economic domain. Additionally, actor statements about ecology or institutional reforms were not included to the issue analysis, as neither of these issues can be clearly assigned to the economic or the cultural domain.

In the context of eleven election campaigns under scrutiny, political parties generally adopt populist rhetoric on economic issues $(\mathrm{M}=0.062)$ more frequently than on cultural ones $(M=0.043)$. Again, the variation is quite substantial. The standard deviation for economic populism is 0.085 and 0.051 for cultural populism.

\section{Empirical Analysis}

In the following, the authors begin their empirical investigation by descriptively analysing the levels of populism demonstrated by the selected parties. The authors also provide some qualitative illustrations of populist figures of speech by focusing on the most populist parties in our sample. In a second step, the results of the multivariate analysis are presented.

\footnotetext{
${ }^{6}$ With Cohen's Kappa exceeding 0.6, inter-coder reliability turned out to be satisfactory at the level of these main categories.
} 


\section{Descriptive Analysis}

Table 2 lists the overall levels of populist communication according to party groups.

Consistent with the first hypothesis, populist communication is generally more prevalent at the ideological extremes. Thus, the radical right and the radical left rely on populist appeals in election campaigns more often than mainstream parties. The mean score for the radical right $(\mathrm{M}=0.094)$ proves to be slightly higher than for the radical left $(\mathrm{M}=0.083)$. In contrast, mainstream parties score much lower on the populism indicator (0.031). Parties from the left (0.034) are slightly more populist than those from the right $(0.029)$. This is primarily due to the fact that the Greens prove to be somewhat more populist than average (0.044). This comparatively high level may reflect the legacy of these parties, as they were rather populist in the 1970s and 1980s (March 2007: 66). With respect to the mainstream right, parties such as the Popular Party for Freedom and Democracy (VVD) from the Netherlands and Civic Choice (SC) from Italy also made rather extensive use of populist campaign communication (0.071 for both). When looking at the country level, it appears that radical parties exhibit consistently higher levels of populist communication in ten out of eleven cases. The only exception concerns the 2013 Italian general elections (see Table A.1 in the Appendix).

Table 2: Levels of populism according to ideological groups

\begin{tabular}{|lcccc|}
\hline & All statements & Economic issues & Cultural issues & $\mathrm{N}$ \\
\hline Radical right & 0.094 & 0.113 & 0.093 & 10 \\
Radical left & 0.083 & 0.131 & 0.058 & 10 \\
Mainstream parties & 0.031 & 0.034 & 0.027 & 42 \\
- Mainstream left & 0.034 & 0.039 & 0.040 & 16 \\
- Mainstream right & 0.029 & 0.030 & 0.019 & 26 \\
& 0.050 & 0.062 & 0.043 & 62 \\
\hline
\end{tabular}

As far as concerns the radical right, all selected members of this party family are above average in their use of populist communication. The Swiss People's Party (0.239) proves to be the party that most extensively resorts to populist appeals. In the 2015 federal elections, the 
party decided to play the 'populist card' against the backdrop of the so-called 'asylum crisis', when reports about thousands of migrants attempting to enter Western European countries dominated the headlines (Bernhard 2016). In this context, the SVP attracted great attention by announcing that it would challenge a reform of the Swiss asylum law by means of a nationwide referendum. ${ }^{7}$ The party made extensive use of people-centrism, anti-elitism and demands for popular sovereignty on the asylum topic. For example, in its press release issued on 25 September 2015, the party accused the federal authorities of 'deliberately throwing sand into the people's eyes.' The party picked out two provisions of the bill in its communication the fact that asylum-seekers would be granted free legal advice, as well as the possibility that the federal government would conduct expropriations as a last resort in order to build new asylum centres. The SVP stated that it opposed these 'unsuitable and dangerous policies at the expense of the citizens'. On 6 October 2015, the party's governing board confirmed its decision to launch a referendum. In the press release of that day, the party concluded: 'To the SVP it is clear that the people should have the final say on this bill.'

Regarding the radical left, the KKE, the Greek Communists (0.230) and SYRIZA (0.167) exhibit the highest degrees of populist campaign communication. In the framework of the Greek legislative elections in January 2015, which included a salient public debate on an agreement for a third bailout package provided by the Troika (Rori 2016), SYRIZA largely relied on populist appeals when it decided to attack the neoliberal austerity measures of the incumbent government, a coalition between New Democracy and PASOK. In a press release published on 23 November 2014, ahead of the vote for the new budget in Parliament, SYRIZA stated that 'the government reduces social expenditures, increases taxes, and cancels any development prospect. At the same time, and in the same destructive logic, it announces privatizations against public property and the interests of the Greek people. (...) What is

\footnotetext{
${ }^{7}$ This decision took most observers by surprise, given that the rather technical streamlining reform both chambers of Parliament had just adopted aimed at speeding up asylum procedures.
} 
certain is that this budget will not be executed because it will be cancelled by the vote of the Greek people.' In a similar vein, an important party figure made the following statement on 29 November 2014, in the aftermath of a national strike regarding imminent cuts on salaries and pensions: 'The workers, the unemployed, and the pensioners, with yesterday's incredible participation to the strike protest rallies opened up a new victorious circle of labour and popular struggles that will lead - with their vote as well - to the overturn of the government before it manages to destroy whatever is left standing of the pensions. A left-wing government that will arise with the vote and the trust of the people will support public social security and pensions, with the first step in that direction being the reconstitution of the $13^{\text {th }}$ pension instalment (Christmas present) for those who receive salaries of 700 Euros and less.' For their part, the Greek Communists forcefully made use of populist figures of speech when expressing their hostility towards the European Union. Addressing the EU's strategy 'Europe 2020', a deputy of the KKE claimed on 25 November 2014, that it 'was planned and is being realised by the EU and the neoliberal governments to serve one and only one target: To safeguard and enhance the greed of the monopolies on the remnants of the life and rights of the working class people. This policy doesn't have any "social dimensions," it serves the need of capital for very cheap labour power; it leads to the widening of extreme poverty and social exclusion for the working class and the poor popular sectors'. More generally, the Greek Communists used to portray themselves as the only serious opposition that could safeguard the interests of the working class. On 22 January 2015, General Secretary Dimitris Koutsoumpas posited, in a populist manner, that 'all other parties co-travel in the wagon running on the EU and NATO, IMF an ECB rails, are willing to co-govern or to push whatever government to become more conservative. All the parties except for the KKE are determined to lead the people to be exploited by the rich, to produce profit from the sweat of the working people.' Anticipating a victory for SYRIZA, he further maintained that this party 
'is allied with sectors of the big capital. It is being tested by the crows of the markets, the imperialist think-tanks of the USA and elsewhere.'

The results also demonstrate the levels of populism according to issue domains. With respect to cultural populism, the radical right (0.093) exhibits higher average scores than the radical left $(0.058)$ and mainstream parties (0.027). This basic pattern supports the second hypotheses. The highest means for the radical right come from the Swiss People's Party (0.233), ANEL (0.167), UKIP (0.153) and the Party for Freedom (0.139). In the case of the remaining parties, SYRIZA most frequently relied on cultural populism (0.203) by far, most notably when addressing European integration issues.

A different picture emerges from the analysis of ideological groups in terms of economic populism. With an average score of 0.131 , parties from the radical left exhibit a somewhat higher degree of populist campaign rhetoric than those from the radical right (0.113). Once again, mainstream parties turn out to be noticeably less populist (0.034). When taking a closer look at individual parties, it appears that the Greek Communists massively relied on economic populism (0.524). However, the KKE is far from being an exception in the Greek elections of January 2015. Next in line are Golden Dawn (0.333), ANEL (0.250), and SYRIZA (0.216). As to the geographical region, this study distinguishes between the 19 parties from Southern Europe (Italy, Spain, Greece and Portugal) and the 43 from Northern Europe (Austria, France, Germany, the Netherlands, Sweden, Switzerland and the United Kingdom). The former $(M=0.052)$ are only slightly more populist than the latter $(M=0.048)$. However, there is an indication of a difference on economic issues, given that the Southern parties $(\mathrm{M}=0.095)$ are roughly twice as populist as those from the North $(\mathrm{M}=0.047)$. These figures support the fourth hypothesis. Finally, parties from the North only somewhat more frequently rely on cultural populism $(\mathrm{M}=0.048)$ than those from the South $(\mathrm{M}=0.042)$. 
When examining the eleven elections under scrutiny, it appears that the Greek parties are the most populist in general $(\mathrm{M}=0.088)$. Among the remaining Southern countries, only the parties from Italy $(\mathrm{M}=0.060)$ turn out to be somewhat above average, while those from Spain $(\mathrm{M}=0.027)$, and especially those from Portugal $(\mathrm{M}=0.008)$, are much less populist than the average European party. In other words, the four contexts from the South are far from forming a homogenous block. In the elections of the Northern countries, the levels of overall populist communication prove to be subject to less variation, given that the corresponding figures range from 0.030 (for the United Kingdom) to 0.071 (for the Netherlands). In terms of economic populism, the most striking result relates to the extraordinarily high level of economic populism that occurs in the case of the January 2015 Greek elections $(\mathrm{M}=0.189)$, followed by the 2013 Italian general elections (0.089). With respect to cultural populism, the country-level variation proves to be much smaller. The maximum refers to the Greek national elections $(\mathrm{M}=0.079)$, followed by the elections held in the Netherlands $(0.068)$ and in the United Kingdom (0.064).

In the multivariate analysis, the influence of pre-election status is controlled for by taking into account government participation and party age. When it comes to the use of populist communication in electoral contests, scholars believe that the parties in office are generally less inclined to rely on populist rhetoric than challengers (Mény and Surel 2002; Bonikowski and Gidron 2015; Ernst et al. 2017). In an attempt to replace governing parties, the latter can be expected to make more frequent use of the populist toolbox. Simple bivariate analyses show that, on average, the 23 governing parties in our sample are less prone to use populist rhetoric $(\mathrm{M}=0.036)$ than the 39 opposition and challenger parties $(\mathrm{M}=0.058)$. The difference is similar in the case of cultural issues (M: 0.032 vs. 0.055 ), but it is larger for economic issues (M: 0.028 vs. 0.082 ). In addition, newly emerging parties can be expected to rely more frequently on populist communication than older ones, thus taking advantage of their image 
of a 'fresh force' in the national political landscape. The authors account for party age by subtracting the founding year from the year in which the selected elections took place. Correlations between party age and populist levels prove to be rather low and even slightly positive in the economic domain. Pearson's $\mathrm{R}^{2}$ is -0.11 for all statements, 0.03 for economic issues and -0.08 for cultural ones.

\section{Multivariate Analysis}

The results of the multivariate analysis are as follows. Table 3 presents the results of six OLS regressions that explain the degree of populism exhibited by the 62 selected parties. Let us begin by addressing the first three models. Model I refers to all statements, while Model II focuses on economic issues and Model III on cultural issues. In addition to party groups (radical left, radical right and mainstream parties) and a dichotomous variable for geography ( $1=$ South, $0=$ North), each estimation considers government participation and the age of the

parties. The first model confirms that both the radical left and the radical right excel in terms of overall populist communication. In support of the first hypothesis, these two types of parties significantly rely on populism and do so more extensively than mainstream parties, which serve as reference category.

Model 2 supports the second hypothesis. The results show that only parties from the radical right make use of populist statements on cultural issues more frequently than mainstream parties. However, based on the coefficients reported in Model 3, the third hypothesis must be rejected. The results indicate that both groups at the ideological extremes tend to resort to populist campaign rhetoric regarding economic issues more often than mainstream parties. The expectation was that the radical left would be more populist on this issue dimension. 
Table 3: OLS regression models explaining levels of populism

\begin{tabular}{|c|c|c|c|c|c|c|}
\hline & $\begin{array}{c}\text { Model I } \\
\text { All } \\
\text { statements }\end{array}$ & $\begin{array}{l}\text { Model II } \\
\text { Cultural } \\
\text { issues }\end{array}$ & $\begin{array}{c}\text { Model III } \\
\text { Economic } \\
\text { issues }\end{array}$ & $\begin{array}{l}\text { Model IV } \\
\text { All } \\
\text { statements }\end{array}$ & $\begin{array}{l}\text { Model V } \\
\text { Cultural } \\
\text { issues }\end{array}$ & $\begin{array}{c}\text { Model VI } \\
\text { Economic } \\
\text { issues }\end{array}$ \\
\hline Radical right & $\begin{array}{c}0.066^{* * *} \\
(4.31)\end{array}$ & $\begin{array}{c}0.064^{* * *} \\
(3.66)\end{array}$ & $\begin{array}{l}0.081^{*} \\
(2.84)\end{array}$ & $\begin{array}{c}0.060^{* * *} \\
(4.08)\end{array}$ & $\begin{array}{c}0.059^{* * *} \\
(3.41)\end{array}$ & $\begin{array}{l}0.063^{*} \\
(2.57)\end{array}$ \\
\hline Radical left & $\begin{array}{c}0.057^{* * *} \\
(3.60)\end{array}$ & $\begin{array}{l}0.031 \\
(1.69)\end{array}$ & $\begin{array}{l}0.079^{*} \\
(2.67)\end{array}$ & $\begin{array}{c}0.057^{* * *} \\
(3.73)\end{array}$ & $\begin{array}{l}0.030 \\
(1.70)\end{array}$ & $\begin{array}{l}0.077^{* *} \\
(3.05)\end{array}$ \\
\hline South & $\begin{array}{l}-0.008 \\
(-0.64)\end{array}$ & $\begin{array}{l}-0.011 \\
(-0.87)\end{array}$ & $\begin{array}{l}0.034 \\
(1.53)\end{array}$ & & & \\
\hline Greece & & & & $\begin{array}{l}0.022 \\
(1.36)\end{array}$ & $\begin{array}{l}0.013 \\
(0.65)\end{array}$ & $\begin{array}{c}0.124^{* * *} \\
(4.59)\end{array}$ \\
\hline $\begin{array}{l}\text { Remaining } \\
\text { South }\end{array}$ & & & & $\begin{array}{l}-0.025 \\
(-1.90)\end{array}$ & $\begin{array}{l}-0.027 \\
(-1.69)\end{array}$ & $\begin{array}{l}-0.020 \\
(-0.88)\end{array}$ \\
\hline $\begin{array}{l}\text { Government } \\
\text { participation }\end{array}$ & $\begin{array}{l}0.004 \\
(0.29)\end{array}$ & $\begin{array}{l}-0.008 \\
(-0.55)\end{array}$ & $\begin{array}{l}-0.019 \\
(-0.85)\end{array}$ & $\begin{array}{l}0.002 \\
(0.16)\end{array}$ & $\begin{array}{l}-0.009 \\
(-0.66)\end{array}$ & $\begin{array}{l}-0.025 \\
(-1.27)\end{array}$ \\
\hline Party age & $\begin{array}{c}0.0002 \\
(0.13)\end{array}$ & $\begin{array}{c}0.0000 \\
(0.06)\end{array}$ & $\begin{array}{l}0.0003 \\
(1.52)\end{array}$ & $\begin{array}{c}0.0000 \\
(0.13)\end{array}$ & $\begin{array}{c}0.0001 \\
(0.05)\end{array}$ & $\begin{array}{c}0.0004 \\
(1.76)\end{array}$ \\
\hline Constant & $\begin{array}{l}0.030^{* *} \\
(2.63)\end{array}$ & $\begin{array}{l}0.033^{*} \\
(2.54)\end{array}$ & $\begin{array}{l}0.015 \\
(0.72)\end{array}$ & $\begin{array}{c}0.032^{* *} \\
(2.92)\end{array}$ & $\begin{array}{c}0.035^{* *} \\
(2.70)\end{array}$ & $\begin{array}{l}0.021 \\
(1.14)\end{array}$ \\
\hline$N$ & 62 & 62 & 62 & 62 & 62 & 62 \\
\hline $\operatorname{Adj} . R^{2}$ & 0.285 & 0.255 & 0.230 & 0.350 & 0.220 & 0.155 \\
\hline
\end{tabular}

${ }^{(*)} \mathrm{p}<0.10 ;{ }^{*} \mathrm{p}<0.05 ;{ }^{* *} \mathrm{p}<0.01{ }^{* * *} \mathrm{p}<0.001 ; \mathrm{T}$-values in brackets.

The mainstream parties are the reference category for the ideological groups.

As Model III demonstrates, there is no evidence for a North-South divide on economic matters. Contrary to the impression derived from the descriptive analysis, it appears that the parties from the South do not resort to populism more frequently in general than those from the North. This finding contradicts the fourth hypothesis. To delve deeper into the populist influence of Southern parties, in the three additional models of Table 3, the authors replaced 
the dichotomous variable with a similar indicator for Greek parties, on the one hand, and for the remaining Southern parties from Italy, Spain, and Portugal, on the other hand. Model VI shows that the Greek parties exhibit higher levels of economic populism than their peers. This result can be linked to the extraordinary severity of the crisis that occurred in Greece in the context of the January 2015 elections.

In contrast, Models IV and V suggest that the Greek parties, the remaining Southern parties and those from the North, do not significantly distinguish between themselves in the use of populism in general nor with regard to cultural issues. Additionally, there are no statistically significant effects with respect to the control variables. The six regression models indicate that government parties and older parties are not less inclined to rely on populism than opposition and younger parties.

The authors also tested some alternative specifications to the standard models. Thus, they obtained the same results in terms of significance by classifying the Five Star Movement as a residual party, a radical right party and even a mainstream party. This also holds true when replacing M5S, for which the authors had to rely on blog posts instead of press releases, with either Left Ecology Freedom (SEL) or Civil Revolution (RC), two radical left parties which failed to obtain four per cent of the vote in the 2013 Italian general elections. Moreover, the authors further examined the radical parties and did not find any statistically significant effect for the radical left parties from the Southern region of Western Europe or for the radical right parties that have economically moved to the left (i.e. the Freedom Party of Austria, the National Front, the Party for Freedom from the Netherlands and the Sweden Democrats). Following the recommendations made by two reviewers, the authors also included a series of interaction terms between the radical right and Southern European parties into our standard models. With the exception of a positive effect of Southern radical right parties on economic 
issues, the coefficients turned out to be insignificant. This indicates that radical parties from the South are not generally exceptionally populist.

\section{Conclusion}

There is no doubt that populism is on the rise in contemporary Europe (Mudde 2015). Numerous political parties that are commonly labelled as populist have succeeded in durably establishing themselves as powerful players in their respective countries. This article studies the levels of populism exhibited by parties in the context of eleven recent election campaigns. The empirical analysis relies on a content analysis of press releases. Consistent with our theoretical expectation, parties from the radical right and the radical left rely on populist appeals more frequently than their mainstream counterparts. In other words, the strongest expressions of populism are at the extremes of the ideological spectrum. Conversely, this study confirms that mainstream parties are less prone to rely on populism (Rooduijn et al. 2014), rejecting the thesis of a general populist Zeitgeist. This pattern of bipolarity supports earlier comparative studies that focus on the more ideological dimension of populism by looking at party manifestoes, and it parallels current research findings obtained in the realm of new social media (Ernst et al. 2017).

However, the authors would like to warn against equating radicalness with populism. Indeed, ideological extreme parties cannot simply be regarded as populist for two main reasons. First,

the phenomenon of populism should be considered a matter of degree. Hence, instead of using categorical indicators, the authors relied on a gradual measure in the framework of this empirical analysis. This indicator reveals that parties that are commonly classified as populist sometimes vary greatly in their reliance on populist appeals. Second, it is important to account for deviating cases. Our study demonstrates that some radical parties display below average levels of populism. This is most visible for the Communists from Portugal. At the same time, 
few mainstream parties (such as Popular Party for Freedom and Democracy - VVD - from the Netherlands, Civic Choice - SC - from Italy and some Green parties) make extensive use of populist campaign rhetoric.

Additionally, this investigation reveals that the phenomenon of populism is not confined to the radical right in contemporary Western Europe. This is of primary importance, given that the academic literature has long neglected left populism. Scholars of populism are thus well advised to devote more attention to this phenomenon. This seems to be even more relevant when considering electoral performance. Indeed, in the Eurozone, populist parties from the left are currently stronger in electoral terms than those from the right. March and Keith (2016) argue that the Great Recession has decisively contributed to boosting left populism in the last few years. According to this reasoning, the success of left populists is due to the fact that these parties usually mobilise voters using economic and class-related terms.

This empirical analysis further provides analysis at the level of issue domains. It shows that the radical right parties are more populist when cultural issues are at stake, thereby confirming the second hypothesis. However, the empirical investigation does not ultimately support the expectation that parties from the radical left resort to populism more frequently than the remaining parties. Given that the multivariate analysis finds that both radical groups are more prone to resort to populism than mainstream parties, the third hypothesis had to be rejected. The rather high reliance on populism by the radical right may be attributed to the fact that most of the selected elections took place in the shadow of the Great Recession. Due to the saliency of the crisis and its consequences, the radical right may have felt compelled to play the populist card in the economic domain more often than under ordinary circumstances. Additionally, the authors plead for a more fine-grained examination of these issues in future research. More specifically, scholars may assess whether, and to what extent, the specific contents of the populist appeals vary between radical groups on either side of the class divide. Unfortunately, the number of coded statements did not allow us to further disaggregate the 
magnitude of populism to the level of single issues. Another limitation of this analysis is its cross-sectional research design, since it only selected one election per country. Given that the authors do not have data on pre-crisis elections, only a snapshot of post-crisis elections, they are unable to posit any causal relationship about the effect of the crisis. A proper identification strategy would require at least one data point before the eruption of the crisis and one afterwards. This also holds true for the fourth hypothesis about the presumed NorthSouth divide, which had to be rejected. In the absence of a systematic change analysis, the question of whether populism increased due to the crisis could not be addressed. It may be the case that the parties in the countries that were most hard hit by the economic and financial crisis (e.g. Greece and Italy) had already adopted stronger populist rhetoric at the outset of the crisis than parties from other countries. However, the emergence of new populist actors such as Podemos and the Five Star Movement, as well as the fact that mainstream parties largely refrained from using populist communication in the crisis-ridden January 2015 Greek legislative elections, suggest otherwise. 


\section{Disclosure statement}

No potential conflict of interest was reported by the authors.

\section{Notes on contributors}

Laurent Bernhard is a senior researcher at the Swiss Centre of Expertise Research in the Social Sciences (FORS) which is hosted by the University of Lausanne. His main research interests include populism, direct democracy, political communication, and asylum policies. [laurent.berhard@fors.unil.ch]

Hanspeter Kriesi holds the Stein Rokkan Chair in Comparative Politics at the European University Institute in Florence. He is also affiliated to the Laboratory for Comparative Social Research, National Research University Higher School of Economics, Russian Federation. He is currently working on an ERC project on the political consequences of the Great Recession in Europe.

[hanspeter.kriesi@eui.eu] 


\section{References}

Aslanidis, Paris (2015). 'Occupy Wall Street, European Indignados: Social Movements in Comparative Perspective - Is Populism the Common Denominator?' Workshop on Inside and Outside Southeastern Europe, Humboldt University Berlin.

Bernhard, Laurent (2016). 'The 2015 Swiss Federal Elections: The Radical Right Strikes Back', West European Politics, 39:4, 879-889.

Bernhard, Laurent, Kriesi, Hanspeter Kriesi, and Edward Weber (2015). 'The Populist Discourse of the Swiss People's Party', in Hanspeter Kriesi and Takis S. Pappas (eds.), European Populism in the Shadow of the Great Recession. Colchester: ECPR Press, 123-137.

Betz, Hans-Georg (1993). 'The New Politics of Resentment: Radical Right-Wing Populist Parties in Western Europe', Comparative Politics, 25:4, 413-427.

Betz, Hans-Georg, and Carol Johnson (2014). 'Against the Current-Stemming the Tide: The Nostalgic Ideology of the Contemporary Radical Populist Right', Journal of Political Ideologies, 9:3, 311-327.

Biorcio, Roberto (2015). Il populismo nella politica italiana : Da Bossi a Berlusconi, da Grillo a Renzi. Milano: Mimesis.

Bonikowski, Bart, and Noam Gidron (2015). 'The Populist Style in American Politics: Presidential Campaign Discourse', 1952-1996. Social Forces, 94:4, 1593-1621.

Bordignon, Fabio, and Luigi Ceccarini (2013). 'Five Stars and a Cricket. Beppe Grillo Shakes Italian Politics', South European Society and Politics, 18:4, 427-449.

Bornschier, Simon (2010). Cleavage Politics and the Populist Right: The New Cultural Conflict in Western Europe. Philadelphia: Temple University Press. 
Bruhn, Kathleen (2012). 'To Hell With Your Corrupt Institutions!: AMLO and Populism in Mexico', in Cas Mudde and Cristobàl Rovira Kaltwasser (eds.), Populism in Europe and the Americas: Threat or Corrective for Democracy?, Cambridge: Cambridge University Press, 88-112.

Canovan, Margaret (1981). Populism. New York: Harcourt Brace Jovanovich.

Canovan, Margaret (1999). 'Trust the People! Populism and the Two Faces of Democracy', Political Studies, 47:1, 2-16.

Castanho Silva, Bruno (2017). Contemporary Populism: Actors, Causes and Consequences Across 28 Democracies, PhD thesis, Central European University.

Conti, Nicolò, and Vincenzo Memoli (2015). 'The Emergence of a New Party in the Italian Party System: Rise and Fortunes of the Five Star Movement', West European Politics, $38: 3,516-534$

Ernst, Nicole, Sven Engesser, Florin Büchel, Sina Blassnig, and Frank Esser (2017). Extreme Parties and Populism: An Analysis of Facebook and Twitter Across Six Countries', Information, Communication \& Society, 20:9, 1347-1364.

Gellner, Ernest, and Ghita Ionescu, eds. (1969). Populism: Its Meanings and National Characteristics. London: Weidenfeld and Nicholson.

Hawkins, Kirk A. (2009). 'Is Chávez populist? Measuring Populist Discourse in Comparative Perspective', Comparative Political Studies, 42:8, 1040-1067.

Hermet, Guy (2001). Les populismes dans le monde: une histoire sociologique, XIXe-XXe siècle. Paris: Fayard.

Hobolt, Sara B., and James Tilley (2016). 'Fleeing the Centre: The Rise of Challenger Parties in the Aftermath of the Euro Crisis', West European Politics, 39:5, 971-991. 
Hooghe, Lisbet, Gary Marks, Carole J. Wilson (2002). ‘Does Left/Right Structure Party Positions on European Integration?', Comparative Political Studies, 35:8, 965-989.

Howarth, David (2015). Ernesto Laclau: Post-Marxism, Populism, and Critique. London: Routledge.

Jagers, Jan, and Stefaan Walgrave (2007). 'Populism as Political Communication Style: An Empirical Study of the Political Parties' Discourse in Belgium', European Journal of Political Research, 46:3, 319-345

Kriesi, Hanspeter, Edgar Grande, Romain Lachat, Martin, Dolezal, Simon Bornschier, and Tim Frey (2008). West European Politics in the Age of Globalization. Cambridge: Cambridge University Press.

Kriesi, Hanspeter, and Takis S. Pappas, eds. (2015). European Populism in the Shadow of the Great Recession. Colchester: ECPR Press.

Lane, Philip R. (2012). 'The European Sovereign Debt Crisis', The Journal of Economic Perspectives, 26:3, 49-67.

March, Luke (2007). 'From Vanguard of the Proletariat to Vox Populi: Left-Populism as a 'Shadow' of Contemporary Socialism', SAIS Review of International Affairs, 27:1, 6377.

March, Luke (2011). Radical Left Parties in Europe. London: Routledge.

March, Luke (2017). 'Left and Right Populism Compared: The British Case', The British Journal of Politics and International Relations, 19:2, 282-303.

March, Luke, and Daniel Keith (2016). Europe's Radical left: From Marginality to the Mainstream?. London: Rowman \& Littlefield. 
March, Luke, and Cas Mudde (2005). 'What's Left of the Radical Left? The European Radical Left After 1989: Decline and Mutation', Comparative European Politics, 3:1, 23-49.

Mény, Yves, and Yves Surel (2002). Democracies and the Populist Challenge. Basingstoke: Palgrave.

Mudde, Cas (2004). 'The Populist Zeitgeist', Government and Opposition, 39:4, 542-563.

Mudde, Cas (2010). 'The Populist Radical Right: A Pathological Normalcy', West European Politics, 33:6, 1167-1186.

Mudde, Cas, and Cristóbal Rovira Kaltwasser (2013). 'Exclusionary vs. Inclusionary Populism: Comparing Contemporary Europe and Latin America', Government and Opposition, 48:2, 147-174.

Mudde, Cas (2015). Populism in Europe: A Primer. Open Democracy.

Panizza, Francisco (2005). Populism and the Mirror of Democracy. London: Verso.

Pauwels, Teun (2014). Populism in Western Europe: Comparing Belgium, Germany and The Netherlands. London: Routledge.

Pauwels, Teun (2011). 'Measuring Populism: A Quantitative Text Analysis of Party Literature in Belgium', Journal of Elections, Public Opinion \& Parties 21:1, 97-119.

Priester, Karin. (2012). Rechter und linker Populismus: Annäherung an ein Chamäleon. Frankfurt a. M.: Campus.

Rooduijn, Matthijs, Tjitske Akkerman (2017). 'Flank Attacks: Populism and the Left-Right Radicalism in Western Europe', Party Politics 23:3, 193-204

Rooduijn, Matthijs, Sarah L. de Lange, and Wouter van der Brug (2014). 'A Populist Zeitgeist? Programmatic Contagion by Populist Parties in Western Europe', Party Politics, 20:4, 563-575. 
Rooduijn, Matthijs, and Teun Pauwels (2011). 'Measuring Populism: Comparing Two Methods of Content Analysis', West European Politics, 34:6, 1272-1283.

Rori, Lamprini (2016). 'The 2105 Greek Parliamentary Elections: From Great Expectation to no Expectations', West European Politics, 39:6, 1323-1343.

Rovira Kaltwasser, Cristóbal (2012). 'The Ambivalence of Populism: Threat and Corrective for Democracy’, Democratization, 19:2, 184-208.

Rydgren, Jens (2013). Class Politics and the Radical Right. London: Routledge.

Taggart, Paul A. (2000). Populism. Buckingham: Open University Press.

van Kessel, Stijn (2015). Populist Parties in Europe: Agents of Discontent? Basingstoke: Palgrave Macmillan.

Wirth, Werner, Frank Esser, Martin Wettstein, Sven Engesser, Dominique Wirz, Anne Schulz, Nicole Ernst, Flurin, Daniele Caramani, Luca Manucci, Marco Steenbergen, Laurent Bernhard, Edward Weber, Regula Hänggli, Caroline Dalmus, and Christian Schemer (2016). 'The Appeal of Populist Ideas, Strategies and Styles: A Theoretical Model and Research Design for Analyzing Populist Political Communication', unpublished paper, University of Zurich. 
Appendix:

Table A.1: Levels of populism according to parties

\begin{tabular}{|c|c|c|c|}
\hline Party name & $\begin{array}{l}\text { Ideological } \\
\text { Group }\end{array}$ & $\begin{array}{r}\text { Level of } \\
\text { populism }\end{array}$ & $\begin{array}{l}\text { Number of } \\
\text { statements }\end{array}$ \\
\hline \multicolumn{4}{|l|}{ Austria } \\
\hline Freedom Party of Austria (FPÖ) & Radical right & 0.057 & 301 \\
\hline Team Stronach (TS) & Mainstream & 0.051 & 244 \\
\hline The Greens & Mainstream & 0.028 & 293 \\
\hline NEOS & Mainstream & 0.026 & 85 \\
\hline Social Democratic Party of Austria (SPÖ) & Mainstream & 0.015 & 493 \\
\hline Austrian People's Party (ÖVP) & Mainstream & $\begin{array}{l}0.011 \\
0.032\end{array}$ & 469 \\
\hline \multicolumn{4}{|l|}{ France } \\
\hline National Front (FN) & Radical right & 0.054 & 130 \\
\hline Left Front (FDG) & Radical left & 0.043 & 37 \\
\hline Democratic Movement (MoDem) & Mainstream & 0.038 & 228 \\
\hline Socialist Party (PS) & Mainstream & 0.025 & 200 \\
\hline \multirow[t]{2}{*}{ Union for a Popular Movement (UMP) } & Mainstream & 0.021 & 257 \\
\hline & & 0.036 & \\
\hline \multicolumn{4}{|l|}{ Germany } \\
\hline Alternative for Germany (AfD) & Radical right & 0.073 & 125 \\
\hline The Left (Linke) & Radical left & 0.072 & 276 \\
\hline Alliance90/The Greens & Mainstream & 0.054 & 438 \\
\hline Social Democratic Party (SPD) & Mainstream & 0.047 & 315 \\
\hline Christian Democratic Union (CDU) & Mainstream & 0.009 & 348 \\
\hline \multirow[t]{2}{*}{ Free Democratic Party (FDP) } & Mainstream & 0.005 & 233 \\
\hline & & 0.043 & \\
\hline \multicolumn{4}{|l|}{ Greece } \\
\hline Communist Party (KKE) & Radical left & 0.230 & 63 \\
\hline Coalition of the Radical Left (SYRIZA) & Radical left & 0.167 & 119 \\
\hline Golden Dawn (XA) & Radical right & 0.106 & 56 \\
\hline Independent Greeks (ANEL) & Radical right & 0.051 & 33 \\
\hline The River (To Potami) & Mainstream & 0.049 & 78 \\
\hline Panhellenic Socialist Movement (PASOK) & Mainstream & 0.008 & 72 \\
\hline \multirow[t]{2}{*}{ New Democracy (ND) } & Mainstream & 0.006 & 60 \\
\hline & & 0.088 & \\
\hline \multicolumn{4}{|l|}{ Italy } \\
\hline Civic Choice (SC) & Mainstream & 0.071 & 132 \\
\hline Five Star Movement (M5S) * & Radical left & 0.068 & 148 \\
\hline Northern League (LN) & Radical right & 0.068 & 73 \\
\hline \multirow[t]{2}{*}{ Democratic Party (PD) } & Mainstream & 0.032 & 325 \\
\hline & & 0.060 & \\
\hline \multicolumn{4}{|l|}{ The Netherlands } \\
\hline Party for Freedom (PVV) & Radical right & 0.135 & 57 \\
\hline Socialist Party (SP) & Radical left & 0.085 & 245 \\
\hline PP for Freedom and Democracy (VVD) & Mainstream & 0.071 & 47 \\
\hline Christian Democratic Appeal (CDA) & Mainstream & 0.056 & 71 \\
\hline Labour Party (PvdA) & Mainstream & 0.053 & 167 \\
\hline \multirow[t]{2}{*}{ Democrats 66 (D66) } & Mainstream & 0.025 & 179 \\
\hline & & 0.071 & \\
\hline
\end{tabular}


(Table A.1 continued)

\begin{tabular}{|c|c|c|c|}
\hline Party name & $\begin{array}{l}\text { Ideological } \\
\text { Group }\end{array}$ & $\begin{array}{l}\text { Level of } \\
\text { populism }\end{array}$ & $\begin{array}{l}\text { Number of } \\
\text { statements }\end{array}$ \\
\hline \multicolumn{4}{|l|}{ Portugal } \\
\hline Left Bloc (BE) & Radical left & 0.021 & 540 \\
\hline Communist Party (PC) & Radical left & 0.006 & 236 \\
\hline Socialist Party (PS) & Mainstream & 0.005 & 147 \\
\hline \multirow[t]{2}{*}{ Social Democratic Party (PPD/PSD) } & Mainstream & 0.000 & 148 \\
\hline & & 0.008 & \\
\hline \multicolumn{4}{|l|}{ Spain } \\
\hline We Can (Podemos) & Radical left & 0.042 & 281 \\
\hline Spanish Socialist Workers' Party (PSOE) & Mainstream & 0.038 & 669 \\
\hline Citizens (C's) & Mainstream & 0.017 & 458 \\
\hline \multirow[t]{2}{*}{ People's Party (PP) } & Mainstream & 0.010 & 707 \\
\hline & & 0.027 & \\
\hline \multicolumn{4}{|l|}{ Sweden } \\
\hline Left Party (V) & Radical left & 0.100 & 66 \\
\hline Sweden Democrats (SD) & Radical right & 0.087 & 24 \\
\hline Green Party (MP) & Mainstream & 0.073 & 31 \\
\hline Christian Democrats (KD) & Mainstream & 0.070 & 43 \\
\hline Social Democratic Party (S) & Mainstream & 0.069 & 42 \\
\hline Liberal People's Party (FP) & Mainstream & 0.049 & 36 \\
\hline Moderate Party (M) & Mainstream & 0.042 & 124 \\
\hline \multirow[t]{2}{*}{ Centre Party $(\mathrm{C})$} & Mainstream & 0.032 & 72 \\
\hline & & 0.065 & \\
\hline \multicolumn{4}{|l|}{ Switzerland } \\
\hline Swiss People's Party (SVP) & Radical right & 0.239 & 62 \\
\hline Free Democrats (FDP) & Mainstream & 0.036 & 67 \\
\hline Green Party of Switzerland(GPS) & Mainstream & 0.022 & 86 \\
\hline Social Democratic Party (SP) & Mainstream & 0.021 & 64 \\
\hline Christian Democratic People's Party (CVP) & Mainstream & 0.019 & 40 \\
\hline Conservative Democratic Party (BDP) & Mainstream & 0.010 & 24 \\
\hline \multirow[t]{2}{*}{ Green Liberal Party (GLP) } & Mainstream & 0.010 & 33 \\
\hline & & 0.051 & \\
\hline \multicolumn{4}{|l|}{ United Kingdom } \\
\hline United Kingdom Independence Party (UKIP) & Radical right & 0.073 & 185 \\
\hline Scottish National Party (SNP) & Mainstream & 0.038 & 92 \\
\hline Labour Party (Labour) & Mainstream & 0.018 & 399 \\
\hline Conservative Party (Tories) & Mainstream & 0.012 & 101 \\
\hline \multirow[t]{3}{*}{ Liberal Democrats (Lib Dems) } & Mainstream & 0.011 & 182 \\
\hline & & 0.030 & \\
\hline & & 0.050 & $11 ’ 356$ \\
\hline
\end{tabular}

* As is explained in the data and measures section, the Five Star Movement (M5S) is classified as a radical left party. 